\title{
O SUJEITO PORTA-VOZ É SEMPRE UM NÓS EM CONSTRUÇÃO?
}

\author{
Maria Cleci VENTURINI*
}

- RESUMO: Nosso objeto de estudo, neste espaço, é o discurso sobre o professor, enquanto se sustenta em um discurso o qual chamamos de discurso de e que, em seu funcionamento, sustenta e legitima o dizer e o saber em torno de sujeitos. O corpus de análise é a Revista Nova Escola, designada como "a revista de quem ensina". Entendemos que essa designação coloca num mesmo eixo o sujeito-professor e a escola, simulando, dessa forma, a constituição de um nós diante do qual perguntamos: O sujeito porta-voz é sempre um nós em construção? Concluímos que não, especialmente, no caso em que um dos elementos desse "nós" se coloca na posição daquele que detém o poder e a quem cabe dizer o que é certo e o que é errado. Sustentamos nossas posições nos pressupostos teóricos da Análise de Discurso brasileira, considerando os distanciamentos e as reformulações empreendidas em relação à orientação francesa, proposta por Pêcheux.

- PALAVRAS-CHAVE:Texto. Discurso. Sujeito porta-voz. Enunciado-imagem. Discurso sobre. Discurso de.

Nem o nós nem a identidade que lhe é atribuída, nem a oposição dos dois definem um sujeito. Só há sujeitos, ou melhor, modos de subjetivação políticos, no conjunto das relações que o nós e o seu nome mantêm com o conjunto das "pessoas", o jogo completo das identidades e das alteridades implicadas na demonstração, e dos mundos, comuns ou separados, em que se definem. (RANCIËRE, 1996, p.69).

\section{Inquietações e reflexões sobre o professor e sobre a educação ${ }^{1}$}

As reflexões em torno do professor e do ensino formal têm nos inquietado bastante. Dentre as razões para essa inquietação, sublinhamos nossa atuação durante longo tempo no Ensino fundamental, médio e como formadores de

* UNICENTRO - Universidade Estadual do Centro-Oeste. Departamento de Letras (DELET). Pesquisadora do Laboratório Corpus (UFSM) e do Laboratório de Estudos Linguísticos e Literários (LABELL). Guarapuava - PR - Brasil. 85015-430 - mariacleciventurini@hotmail.com.

1 Ao longo do nosso texto, utilizamos discurso sobre, discurso de, destacamos do, por, no e para e usamos o negrito para destacar essas partículas, especialmente o de e o sobre, ao invés de diferenciarmos o discurso de e do como segundo um discurso que vem de algum lugar de um sujeito, do discurso de, funcionamento como memória, no eixo da constituição (paradigmático). O discurso sobre funciona como atualidade, no eixo da formulação (sintagmático), conforme Venturini (2009a). 
professores nos cursos de Letras. As visibilidades desfavoráveis em torno da imagem do profissional professor e, consequentemente, do ensino aumentam, sobremaneira, essa inquietação devido a notícias divulgadas na mídia, dando visibilidade a agressões de alunos e até de pais ${ }^{2}$ contra professores em espaços escolares. As notícias e reportagens que envolvem professores e a violência de que são protagonistas circulam em jornais e em revistas não especializadas. Entretanto revistas especializadas em educação abandonam o tema violência e, ao falarem de/sobre os professores, emitem, não raras vezes, opiniões desfavoráveis a esses profissionais. Ancoram-se, muitas vezes, no senso comum, na opinião de quem vale de experiências pessoais ou de julgamentos sem valor científico de qualquer ordem.

Diante da avaliação e das visibilidades apontadas, o efeito de sentido que se sobressai é o de que falar sobre o professor e o sobre o fazer pedagógico é uma prática recorrente, não poucas vezes, sem exigência de legitimação ou ancoragem especializada e política. Mesmo assim, as notícias e comentários veiculados na mídia repercutem e mudam comportamentos, tendo em vista a importância do professor na formação social, enquanto formador de opinião que é, ainda que não seja valorizado e esteja sofrendo a violência da sociedade pós-moderna.

Propomos, neste artigo, pensar o professor e o ensino pela noção de sujeito, especificamente, por imaginários constituídos em torno do sujeito e do espaço habitado/significado por ele, priorizando o espaço urbano. De acordo com Rancière (1996, p.69),

[...] só há sujeitos, ou melhor, modos de subjetivação políticos, no conjunto de relações que o nós e seu nome mantêm com "pessoas", o conjunto complexo das identidades e das alteridades implicadas na demonstração, e dos mundos, comuns ou separados, em que se definem.

Retomamos a epígrafe deste artigo, porque o foco do nosso interesse é esse "nós" constituído pelo professor e por aqueles que almejam entrar na ordem do discurso para falar com ele, por ele e sobre ele, buscando legitimar um discurso institucional e constituir imaginários, que recortam realidades e apresentam-nas investidas de valores de verdade, buscando entrar na ordem do discurso, conforme Foucault (2004).

Recortamos, para dar conta dos nossos objetivos, a Revista Nova Escola, tendo em vista que é o veículo midiático que se representa/designa como "a revista de

Ilustramos a violência contra professores, por meio do "sinistro" ocorrido com uma professora do Instituto de Educação de Florianópolis, agredida pela mãe de uma aluna no dia 13 de agosto de 2009. A professora agredida conta que levou mais de 20 tapas no rosto e, depois de caída, ainda levou pontapés, e tudo aconteceu na frente dos alunos, conforme notícia veiculada pelas emissoras de televisão brasileiras e pela internet (PROFESSORA..., 1999). 
quem ensina". Além disso, na quase a totalidade de suas matérias o enfoque está na educação, nas metodologias de ensino e nos problemas que afligem o professor e o ensino. Veicula matérias nas quais o professor é o interlocutor e também o tema. Os sujeitos que ocupam a posição sujeito de locutores, nessa revista, são, em tese, os responsáveis pelo conteúdo do dizer, falam para o professor, do professor e, em muitas delas, sobre o professor. De um lado, a representação do veículo como "a revista de quem ensina" implica inscrição na formação discursiva dos educadores e do ensino. De outro lado, ao falar do lugar do professor e sobre o fazer pedagógico, com vistas a determinar os modos, as razões e os conteúdos do ensino, os locutores do discurso assumem a posição discursiva de sujeito porta-voz. Nessa posição, ao menos em tese, falam em nome de, e sendo assim, deveriam pertencer à mesma formação discursiva do sujeito em nome do qual falam e estariam construindo um "nós", compartilhando opiniões, interesses e saberes.

Diante do discurso sobre o professor e sobre o ensino e da linha editorial da Revista Nova Escola (2008), propomos questões, quais sejam: a posição dos responsáveis pelas matérias veiculadas como sujeito porta-voz do professor e da educação é legítima? Essas matérias refletem as inquietações, expectativas, desejos dos professores e respondem pelas demandas educacionais? O professor, enquanto sujeito do fazer pedagógico, necessita de que lhe digam o que pode/ deve fazer, ou seria mais produtivo dar a ele espaço para a reflexão acerca do seu trabalho por meio de leituras, de cursos de aperfeiçoamento e de encontros com seus pares?

O corpus delimitado é a Revista Nova Escola, número 218, de dezembro de 2008, a matéria "O discurso vazio: as expressões que poucos sabem o que significam", escrita por Moço, Santomauro e Vichessi (2008) por meio da qual buscamos responder às questões acima. Uma das razões desse recorte se traduz pela imagem de capa da revista, na qual se pode ler/ver, dentro de um balão, os dizeres "O Blábláblá da educação". Há destaque, por meio desse enunciado-imagem, para a matéria desenvolvida entre as páginas 4251. Pelo funcionamento da memória, destaca não só o conteúdo da matéria, mas também a tese de que os professores estão falando de coisas que não conhecem e que repetem o senso comum, quando seria de se esperar deles mais cientificidade. Com vistas a dar maior visibilidade ao "vazio do discurso" do professor, na capa da revista, há a tradução do que entendem por "blábláblá". Segundo a revista, trata-se de "expressões que o professor usa sem saber direito o que significam" (REVISTA NOVA ESCOLA, 2008). Para fins de análise, efetuamos três recortes e deles as sequências discursivas (SDRs) a seguir: o enunciado da capa, o título da matéria e um dos exemplos que mostram o que é considerado "discurso vazio". 
Em razão desses procedimentos e das questões que nos inquietam, pretendemos pensar, de um lado, que relações legitimam, ou autorizam a constituição desse "nós", proposto pela Revista Nova Escola" em seu discurso e, de outro, questionar até que ponto o sujeito que fala em nome dos professores e busca ocupar a posição de sujeito porta-voz tem legitimidade para falar em nome de em um discurso em que o professor é o interlocutor e também objeto discursivo. O dispositivo analítico de análise diante do corpus recortado é a noção sujeito porta-voz, seu funcionamento discursivo e a legitimidade dessa posição-sujeito no discurso midiático sobre o professor e sobre o ensino.

O enunciado-imagem é uma noção basilar para nossas reflexões e se sustenta na definição de imagem de Davallon (1999), como "operador da memória social" tomada na instância do Discurso, a partir de Orlandi e Souza (1995) e de Souza (2001) e como enunciado por meio de reflexões realizadas em trabalho anterior (VENTURINI, 2009a). Assim, dizemos que a leitura de textos constituídos por imagens realiza-se por meio de enunciados-imagem, que significam pelo interdiscurso. A imagem, nessa abordagem, funciona como enunciado "pois incorpora elementos do pré-construído, que se produzem no exterior do discurso e organizam a repetição [...] provocando, eventualmente, apagamentos, esquecimentos e, às vezes, a denegação." (VENTURINI, 2009a, p.130-131).

Colocadas as questões de pesquisa, o corpus de análise e o dispositivo analítico, dois esclarecimentos se fazem necessários em relação aos procedimentos metodológicos pelos quais as análises são possíveis. O primeiro diz respeito à terminologia usada para nomear os recortes, ou seja, sequência discursiva de referência (SDR) empregada por Courtine (1981) e definida por ele como discurso concreto duplamente determinado pelas formações ideológicas e pela autonomia relativa da língua. Nesse sentido, de um lado, as formações ideológicas remetem ao discurso as formações discursivas definidas. De outro lado, pela autonomia relativa da língua, elas sinalizam que as palavras, segundo Pêcheux (1997, p.160), "[...] mudam de sentido segundo as posições sustentadas por aqueles que as empregam, o que quer dizer que elas adquirem seu sentido em referência a essas posições, isto é, em referência às formações ideológicas [...] nas quais essas posições se inscrevem." Courtine (1999, p.10) diz que o analista trabalha com o discurso o que significa trabalhar não com a língua homogênea, objeto dos linguistas, mas com o que é da ordem do enunciável, " [...] a ordem que constitui o sujeito falante em sujeito de seu discurso e ao qual ele se assujeita em contrapartida." Trata-se, no presente texto, de analisar por meio do linguístico a relação entre as formações ideológicas e formações discursivas e os efeitos de sentido constituídos no discurso. 
O segundo esclarecimento diz respeito à análise dos três recortes por meio da noção enunciado-imagem que analisamos como o que irrompe no eixo da formulação pelo interdiscurso, que, segundo Pêcheux (1997, p.167), constituise no intradiscurso como um efeito sobre si mesmo, como "uma interioridade inteiramente determinada como tal do exterior." Esse procedimento é pertinente, uma vez que as sequências de referência estruturam-se por enunciados-verbais, mas, também, por enunciados-imagem materializados por balões e por riscos presentes na matéria da revista. Os primeiros significam o discurso (vazio, sem fundamentos teóricos adequados), e o segundo sinaliza para as correções feitas nos enunciados formulados pelos professores por aqueles que analisam o discurso desses profissionais. A correção se deve ao fato de os professores, segundo os locutores, realizarem "discursos vazios" e "distorcerem" as teorias que ancoram os seus dizeres ou a sua prática pedagógica.

Diante das questões e inquietações referidas acerca do que se diz para, do e sobre o professor e a educação na mídia, especificamente, na Revista Nova Escola. Propomo-nos a assumir posições teóricas que nos possibilitem responder a essas questões, buscando saber até que ponto os que escrevem na "revista de quem ensina" representam, pelo seu discurso, "um nós em construção" a que se refere Pêcheux, no texto de 1982 - publicado no Brasil em 1990 -, quando retoma os posicionamentos de Conein (1980).

A tomada de posição de Pêcheux em torno da noção sujeito porta-voz, segundo Maldidier (2003, p.71), representou "a abertura para as disciplinas sócio-históricas" e, por essa abertura, a renovação da problemática do discurso, introduzindo e deslocando essa noção das disciplinas sócio-históricas para os aportes teóricos na Análise de Discurso, que é fundamental em nossa análise, tendo em vista que a nossa questão é saber até que ponto "a revista de quem ensina" é porta-voz do sujeito-professor, mais especificamente, se há um "nós" em construção funcionando nesse discurso.

Pelas formulações realizadas em torno dessa noção no texto "Delimitações, inversões e deslocamentos", Pêcheux (1990) assume, mais uma vez, que a AD é uma disciplina de entremeio, e isso significa tomar e tornar produtivas noções advindas de outras disciplinas. Em relação à noção sujeito porta-voz, fio condutor de nossas análises, ancoramo-nos nas posições teóricas de Conein (1980). Essa obra é retomada em Pêcheux - em 1982, ${ }^{3}$ publicada no Brasil em 1990 - da qual acolhemos os deslocamentos efetivados pelo fundador da Análise do discurso. Finalmente, reportamo-nos a outros estudiosos para os quais essa noção faz sentido e é produtiva.

3 Utilizamos em nosso texto a publicação brasileira de 1990. 


\section{Entrelaçando análises e teoria}

A primeira posição que assumimos do lugar de onde olhamos o discurso é que o vemos como uma prática política, à medida que os textos constitutivos desse discurso se realizam por sujeitos e em torno de sujeitos, que se inscrevem em formações discursivas, e, a partir dessa inscrição, se identificam, contra-identificam ou se desidentificam a determinados saberes e poderes. Por esse processo, os sujeitos exercem o direito de poder/dever fazer e dizer, o que lhes é facultado pelo funcionamento da ideologia. Nesse sentido, esses sujeitos se inscrevem, pelo trabalho da língua na história, na ordem do repetível (paráfrase) ou na ordem do que rompe com o mesmo e instaura o novo (polissemia). Sustentamos, por meio dessas posições, que no exercício desse poder e desse saber em que funciona a instância do imaginário, o sujeito veja a si mesmo e o Outro e se coloca no lugar em que desse outro. Ao assumir esse lugar, de acordo com Pêcheux (1997, p.214), o sujeito assume também a responsabilidade pelo dizer "na medida em que lhe é atribuído o encargo pelos conteúdos colocados".

O sujeito se constitui pelo esquecimento de que o dizer existe antes dele e, por isso, não vê que as palavras, como diz Orlandi (2002, p.32), não são só suas "elas significam pela história e pela língua". O que é dito em outro lugar significa nas "nossas palavras." Com isso, reiteramos na esteira desses autores, que a dimensão imaginária faz parte do funcionamento da linguagem, simulando realidades e efeitos de evidência que sustentam e dão visibilidade a certas "realidades" e apagam outras. Enfim, por meio dessas reflexões, sustentamos e legitimamos nossa visão de discurso como uma prática política medida que a instância do imaginário dá uma direção ideológica, uma ancoragem política ao texto, tendo vista que ele sempre significa em um discurso, por meio de sujeitos, não são só interpelados pela ideologia, mas também atravessados pelo inconsciente.

A segunda posição que desejamos assumir em relação ao discurso sobre o professor e sobre o ensino é que ele se ancora em um discurso anterior, que chamamos de discurso de e se constitui no eixo paradigmático e funciona pelo interdiscurso, o qual segundo Silveira (2004), é um lugar porque os sentidos estão nele, mas só significam quando convocados por formações discursivas. 0 discurso de, segundo Venturini (2009a, p.73), sustenta o discurso no intradiscurso pela constituição de "pontos de estabilização que o legitimam e ancoram pela repetição, pelos procedimentos de 'fazer-crer' e de 'fazer-ver'". Neste mesmo trabalho, dissemos que esse discurso constitui a rememoração, que ocorre na dimensão não linear do dizer, ocupando o espaço do já-dito e do significado antes em outro lugar, cujo retorno se dá pela repetição, que de um lado estabiliza o sentido e de outro constitui a possibilidade do novo por meio de processos parafrástico, isto é, a manutenção de algo sempre em todo dizer. Trata- se do dizível, da memória. 
A rememoração em seu funcionamento como interdiscurso sustenta o discurso sobre e funciona pelo atravessamento do inconsciente, isto porque, o que é lembrado ou esquecido e retorna como memória não faz parte das escolhas do sujeito, mas de demandas, desejos do sujeito e da formação social e, na maioria das vezes, atendem a interesses institucionais. Apesar da institucionalização, a língua falha, o sentido escapa pelos espaços onde o sujeito, constituído pela ilusão de ser a fonte do sentido, busca regulá-lo, domesticá-lo.

O discurso sobre, que se funda no discurso de, funciona, com frequência, como uma modalidade de discurso pedagógico, que no eixo da formulação, ocorre como um discurso saturado, sem espaço para as contradições próprias do discurso, na perspectiva teórica da análise do discurso, de filiação pecheuxtiana. Assim, entendemos que a rememoração e a comemoração e funcionam juntas no intradiscurso, à medida que a rememoração - eixo vertical - constitui redes parafrásticas, que inscrevem a repetição em redes de sentido. A comemoração - eixo horizontal - movimenta, reformula e transforma o dizer e pelo processo polissêmico, possibilita novos sentidos, novas inscrições do sujeito a redes de memória. Em relação ao funcionamento do discurso sobre o professor e sobre a educação dá visibilidade a uma memória que retorna em discurso, ancorando-se em discursos de outros tempos.

A terceira posição assumida em relação ao discurso sobre o professor e sobre o ensino tem a ver com o funcionamento do sujeito porta-voz. Entendemos que a Revista Nova Escola (2008), ao representar-se como "a revista de quem ensina", constitui lugares de autoridade e efeitos de verdade que resultam de um exercício de poder, podendo-se dizer que é uma das formas de institucionalização do dizer, que se materializa no fio do discurso pela ocorrência de palavras como "dever", "poder", "ter de". Outros procedimentos discursivos do discurso sobre são as definições, os efeitos de saturação pelos procedimentos de fazer crer/fazer ver por meio de dados estatísticos e citações de teorias e autores consagrados, que legitimam o dizer.

Por essas razões, vemos que o locutor desse discurso atua como sujeito porta-voz, podendo assumir duas posições: de enunciador, quando fala em nome de e intermediário, quando faz demandas em nome daqueles em nome dos quais fala. Nessa última posição, assume o lugar de quem resolve os problemas da classe que representa. No entanto, segundo Conein (1980), o porta-voz como enunciador se inclui como membro do grupo em nome do qual fala e se constituindo como "um agente coletivo em movimento", dando visibilidade aos cidadãos e às posições de classe e isso não acontece no discurso da revista em análise, pois nela, os professores são falados, e os locutores analisam esse discurso e tratam o professor como ele, uma terceira pessoa, que não inclui o nós. 
Ainda em relação ao sujeito porta-voz e ao discurso sobre o professor e sobre o ensino, lembramos Pêcheux (1990), que retoma o conceito em tela (sujeito portavoz) em relação à Revolução Francesa, à Revolução Socialista e às revoluções do século XX com o objetivo de analisar os paradoxos próprios do discurso político. Para esse autor, o sujeito porta-voz assume duas posições visíveis: uma como ator, "aquele que se expõe ao olhar do poder que ele afronta"; e outra como agente que resiste e fala "em nome daqueles que ele representa, e sob o seu olhar. [...] que o coloca em posição de negociador em potencial, no centro visível de um "nós' em formação" (PÊCHEUX, 1990, p.17). Circula entre três posições: a de profeta, a de dirigente e a do homem de Estado, constituindo-se como o agente de contradições e deslocamentos, porque circula entre o mundo existente e a possibilidade de "um outro mundo". Nesse funcionamento, é impulsionado pelo germe da resistência, que perturba o campo do político. É em torno desse "nós" que centramos nossas discussões.

Essa mesma noção é trabalhada por Indursky (1999) em relação aos semterra, que adquirem voz política e pública por meio do discurso veiculado pela imprensa. Segundo a autora, eles não falam "são falados". Eles não têm, portanto, diretamente voz, mas enunciam suas demandas sociais por meio do porta-voz, que não se dirige apenas à sociedade, mas também ao Estado, com quem negocia em nome do grupo e, assim como os seus pares, o porta-voz inscreve-se em uma FD que legitima o dizer e as suas demandas. A função do sujeito porta-voz é, portanto, dar visibilidade ao movimento de luta, aos sujeitos que participam desse movimento, sem relatar ou individualizar o dizer empírico do militante em tela. Em resumo, com o seu dizer o enunciador o assume o dizer como mediador entre o MST e a sociedade.

O sujeito porta-Voz, no discurso de rememoração/comemoração no espaço urbano, funciona na dimensão linear do dizer, no intradiscurso e se relaciona com a comemoração a partir do discurso sobre. É responsável pelo que é dito a partir do funcionamento de lugares de memória, uma vez que busca distribuir saberes e dizeres em torno daquele que é o objeto de seu discurso. Com isso, atualiza a memória e possibilitam a constituição de um "nós". É da ordem do mais consciente e lineariza-se na tensão entre o já-dito do interdiscurso, em seu funcionamento pelo pré-construído, como efeito do discurso transverso, no eixo da formulação. Trabalha no plano da reformulação e da reinscrição do dizer, o que faculta a polissemia, a possibilidade do novo. No entanto, o objeto do discurso, no trabalho que desenvolvemos é o objeto do desejo e o objeto a que constitui e faz com que os sujeitos do espaço urbano desejem ser iguais ou semelhante a. Nesse sentido, o discurso sobre, que chamamos de discurso de comemoração, desenvolve-se em torno de um imaginário ideal de sujeito e de espaço. Vemos que isso não ocorre em relação ao discurso sobre o professor e sobre o ensino. 
Assim, é inevitável uma questão: a revista está rememorando/comemorando o professor ou a ela mesma?

Entendemos que a revista em questão fala sobre o professor e sobre o ensino e rememora/comemora a ela mesma, à medida que se autoriza a dizer que o professor está equivocado e que realiza um discurso vazio, muitas vezes, distante da teoria, a qual é na maioria das vezes distorcida. Os sujeitos-locutores não se colocam como parte do grupo, mas como aqueles que sabem o que deveria/ poderia ser feito. Ocupam, portanto, o lugar que deveria/poderia ser do professor. Há, nesse funcionando, uma inversão de valores. Segundo Rosário (2008, p.242),

[...] trata-se um sujeito que não faz parte do grupo que representa e, por conseguinte, não fala do lugar social por ele ocupado [...] um porta-voz não legítimo, não autorizado, configura-se, ainda, no que denominamos de falso mediador, uma vez que, diferentemente do mediador que preserva e respeita a voz do seu grupo - este usurpa e silencia a voz do grupo que pretensamente representa, substituindo-a pelo que pode e deve ser dito a partir de seu próprio lugar social.

O quarto posicionamento que assumimos é que o discurso sobre o professor e sobre o ensino veiculado pela Revista Nova Escola (2008) constitui-se são só por materialidades linguísticas, mas também por imagens, que analisamos a partir da noção enunciado-imagem, cujo funcionamento relaciona-se ao que significa antes em outro lugar, e que irrompe no eixo da formulação, atualizando os sentidos. Dissemos, em trabalho anterior, que "[...] o enunciado-imagem possui uma estrutura interdiscursiva que se inscreve no intradiscurso pela repetição e instaura o efeito memória atualiza e ressignifica o dizer." (VENTURINI, 2009b, p.131). Eles significam em relação ao exterior, a partir de uma interioridade. Nesse sentido, assim como os enunciados-verbais, inscrevem-se em redes de memória.

A partir dessas posições propomos as análises em torno dessa modalidade discursiva, passando antes pelas suas condições de produção e de uma panorâmica sobre a reportagem da qual recortamos sequências discursivas de referência.

\section{Discurso sobre o professor e sobre o ensino na Revista "de quem ensina"}

A matéria selecionada para análise é destaque na capa da revista por meio de imagem de um balão, que significa pensamentos/reflexões, mas pode também sinalizar para devaneios. Ela está assinada por três sujeitos, aos quais não interessa nomear, mas de acordo com investigação realizada, entram na ordem do discurso como autorizados e legitimados para falar sobre o professor e o sobre o ensino. No entanto, na reportagem, não dizem quem são, nem quais suas especialidades. Refletindo em torno disso, podemos dizer que há dois tipos de profissionais da 
educação: os especialistas e aqueles que dão aula para o Ensino Fundamental e Médio. Os primeiros - escritores, pesquisadores - são aqueles que pesquisam, dominam teorias, fazem teses, enfim pensam a educação, mas não chegam a aplicar suas teorias, outros as aplicam por eles. Os segundos - professores, equipe diretiva e pedagógica - na maioria das vezes, enfrentam cargas horárias pesadas e trabalham junto aos alunos, preparam as aulas para os alunos, enfrentem o dia a dia da sala de aula. O foco da nossa discussão não é o valor de cada trabalho, mas a legitimidade de ser sujeito porta-voz de um discurso em relação ao professor. Não nos interessa o conteúdo do dizer, mas os procedimentos que o constituem de valor de verdade e de autoridade.

A matéria inicia com a seguinte afirmativa: "A fala dos educadores brasileiros nunca esteve tão afiada. Conceitos importantes da pedagogia e as práticas de sala de aula mais valorizadas hoje estão na ponta da língua e ajudam a definir o trabalho docente." (MOÇO; SANTOMAURO; VICHESSI, 2008, p.42). Exemplifica a validade do dito; mas, em seguida, coloca um "mas", sinalizando que os professores "falam" de teorias, mas o discurso é vazio e transformam ideias consagradas em jargões. Para mostrar que isso é verdade, selecionaram formulações dos professores e as corrigiram, em azul, riscando. Foram selecionadas dez expressões consagradas pelos professores, mostram a origem delas e o que dizem ser "distorções". O objetivo desse trabalho é "[...] contribuir para colocar um fim nesse "blábláblá" da educação, ajudando a deixar as frases prontas de lado e a se aprofundar no verdadeiro significado das ideias por trás delas - a princípio tão ricas." (MOÇO; SANTOMAURO; VICHESSI, 2008, p.43).

Conforme destacamos anteriormente, quando dizemos "nova escola", retorna ao eixo da formulação "a velha escola", como um discurso de, que sustenta e ancora o discurso em torno da "nova escola". Retorna, também, a história, enquanto memória estabilizada referida pelos historiadores, que é datada e se fundamenta em teorias, que aplicadas ou não, segundo os locutores responsáveis pela matéria os professores repetem e ao fazer isso "distorcem". Talvez o que eles chamam de "distorção" não seja mais que deslocamentos e transformações operadas na teoria, tendo em vista a autonomia relativa da língua e a inscrição de sujeitos a formações discursivas, decorrentes das posições ideológicas assumidas.

Na capa da revista, por meio do enunciado "blábláblá da educação", irrompem domínios de memória, os quais fazem trabalhar no intradiscurso discursos jáditos e significados antes em outro lugar, sinalizando para a contradição e para a opacidade própria da língua, constituída por furos, os quais podem ser preenchidos nem sempre pelo mesmo, mas, também, pelo diferente, instaurando, assim, o novo e, com ele, o equívoco. Podemos iniciar a análise pelo título da revista: "Nova Escola", o qual faz retomar a memória em torno da escola vista como "antiga". Entretanto, no intradiscurso, não há referência ao que seja ou tenha sido "essa 
escola antiga", mas um dos efeitos de sentido diz respeito à modernidade, à melhoria, e isso viria no lugar do que não deu certo, ou foi apagado. Então, a identificação da revista não pode/não é com o professor e com o ensino, mas com "a nova escola", a ser construída por esse veículo, que ao designar-se como a "revista de quem ensina" transforma-se no manual do professor.

Podemos ler/interpretar/compreender pelo espaço de memória em funcionamento nesse lugar, que a escola anterior, substituída por "essa nova escola" constituía-se em torno de problemas de várias ordens, os quais podem ser superados, pois a revista em questão tem compromisso com a mudança, com a transformação e a ela cabe, vemos pelo objetivo proposto na matéria, contribuir para colocar um fim nesse "blábláblá da educação". No entanto, pensando em relação ao sujeito-professor, percebe-se que as mudanças em torno do fazer pedagógico, de um lado, reduzem-se às frases prontas, e, de outro, à repetição de teorias educacionais que nem sempre atendem aos interesses da nova escola. Em relação a isso, cabe questionar o significado de "nova escola", buscando os saberes e os poderes constitutivos do novo. Isso porque vemos retornar ecos do passado, apesar da bibliografia que sustenta o que é dito.

O equívoco maior, em relação ao dito anterior, se constitui pela impossibilidade de identificar os sujeitos/professores de que trata o discurso veiculado na revista. Quem são eles? Todos? Alguns? Atuam no Ensino Fundamental? No Ensino Médio? Isso permite que se pense/veja o outro lado do vazio discursivo sinalizado? Há locutores determinados (os que escrevem a matéria), mas os outros (objetos do discurso e a quem ele se dirige) são "professores", talvez não identificados, anônimos. Esses são nossos gestos de leitura.

A sequência discursiva de referência representada pelo "Discurso vazio", em que o enunciado se constitui por uma imagem de balão sem nada escrito, representa, visualmente, o que seja discurso vazio, enfim "fazendo-ver" "para fazer crer", nos termos de De Certeau (1994). O enunciado-imagem estruturado pelo balão vazio constitui efeitos de sentidos outros, e, por ele, irrompe, no eixo sintagmático, o efeito de sentido do nada, do branco, que satura o discurso e constitui evidências de que não há nenhum conteúdo no dizer do professor. A matéria, da qual retiramos esses enunciados, inicia com a afirmação de que a fala dos educadores nunca esteve tão afiada. Um dos efeitos de sentido constituídos pela relação enunciado-verbal e enunciado-imagem é que os professores sabem do que falam, mas não aceitam mais o mesmo e interpelados pela ideologia e atravessados pelo inconsciente, instauram o novo, talvez sentidos inconscientes, resultantes do desejo de uma "nova escola".

A imagem do balão sem nada dentro diz, sem dizer, que os professores falam de "nada". No entanto a fragilidade de ideias faz retornar e funcionar no eixo da formulação o não dito e que significa, também, o não dizer. No lugar teórico 
em que nos colocamos, dizemos que a língua falha/falta e que o sentido sempre pode ser outro; então dizer que as noções são usadas hoje "com um sentido muito diferente" pode significar transformação/deslizamento/resignificação e, não "ideias frágeis".

Na mesma revista, à página 51, há um texto que se estrutura por meio de enunciados e imagens: texto escrito pelo professor riscado e corrigido. No texto, o sujeito-professor, ou quem o representa, escreveu na sequência 4: "Considerar o saber trazido pelo aluno como um ponto de partida e sempre apresentar a eles novos conhecimentos. Correção realizada: Basear-se somente no saber trazido pelos alunos como parâmetro para determinar o que lhes interessa aprender." (MOÇO, SANTOMAURO; VICHESSI, 2008, p.51).

Segundo os sujeitos-locutores desse discurso, que assumem a responsabilidade pelo dizer, nesta matéria, a questão da realidade foi um dos "carros chefes" da teoria defendida por Paulo Freire. O educador preconiza em seus pressupostos teóricos a necessidade de o ensino considerar os saberes dos alunos, realizando pesquisa prévia anterior com o objetivo de construir e depois trabalhar com os temas geradores. Na sequência acima, as palavras do professor foram corrigidas. Os riscos trazem para o eixo da formulação a desconsideração, a anulação. O efeito de sentido instaurado pelo enunciado-imagem constituído pela correção (riscos) coloca os sujeitos-enunciadores funcionando como professores "da escola velha", que ressoa ela "nova escola". Isso significa dizer, retornam imaginários em torno daqueles que corrigem/riscam/anulam seus interlocutores.

A palavra do sujeito-professor (locutor de um discurso pedagógico) é substituída pela palavra de outro sujeito, o que corrige, detém o saber. Há a substituição de "considerar" por "basear-se", de "um ponto de partida" por "parâmetro para determinar" e de "apresentar a eles" por "o que lhes interessa aprender". Entendemos que são apenas trocas de palavras, mas a desconsideração do sentido das palavras em relação à posição sujeito que fala. "Focar a realidade do aluno" é ensinar o que lhes interessa? E como é que o professor sabe o que interessa a seus alunos? E se nada lhes interessar? A crítica, ao que parece, centra-se no equívoco instaurado pela palavra "focar" e no que ela significava no pensamento freiriano.

Para Paulo Freire, enquanto militante de esquerda, considerar a realidade do aluno significava realizar pesquisa em torno do seu saber com vistas a dar a esse aluno o direito de "saber" mais, preenchendo espaços vazios. Pode-se dizer, em relação a isso, que a sua teoria de Paulo Freire se aproximava do pensamento de Vygotski, não em um texto específico, mas em sua teoria, no seu todo. No entanto, na matéria, não há visibilidade para essa relação. Será que se pode ler essa omissão como um deslizamento inconsciente que "sustenta" o não saber teórico dos professores "dado a ver" na matéria veiculada pela revista? Estaria 
sendo reforçada a tese de que os professores não sabem o que falam a eles e nem do que falam?

\section{Efeito de conclusão...}

Desde o início deste artigo estamos assumindo o discurso como "sempre" político, pois se constitui a partir de sujeitos e para sujeitos. Em relação ao discurso sobre o professor e sobre a educação em relação à designação "revista de quem ensina" entendemos que ao se designar assim, aqueles que "falam" ao professor, do professor e sobre o professor pertencem ao mesmo grupo. Isso significaria que são membros do magistério e, por isso, as matérias veiculadas, na revista, deveriam propiciariam discussões, enfocando os problemas políticos em torno da educação, da valorização do professor e, por que não dizer, falar também de formação continuada. E se assim fosse, aquele que fala sobre o professor, estaria atuando como sujeito porta-voz, ajudando a construir um "nós", fazendo demandas, denunciando as más condições de trabalho, a falta de espaço para leitura, para cursos de aperfeiçoando, a necessidade de o professor "voltar" a ser um pesquisador, um preparador de aula, não um repassador de conteúdos.

A "revista de quem ensina", faz uso de procedimentos discursivos que saturam o discurso, constituindo realidades e verdades pelo imaginário do "fazer-crer" pelo "fazer-ver". Isso se pode observar no enunciado de capa, que recortamos como sequência discursiva de referência 1, a qual utiliza a expressão "blábláblá" e o balão que "traduz" o que quis dizer, como se tudo o que foi traduzido não estivesse homogeneamente significado por esse balão e pela expressão que remete a discurso vazio. O mesmo ocorre na sequência 2 , em que a saturação se traduz pelo balão em branco, que significa não dizer nada. A tradução, que "decifra" sentidos, sinaliza que o sujeito-professor não sabe o que diz e também não sabe interpretar, haja vista a necessidade de intérprete. A sequência 3 completa o circuito: nela o professor passa a ser o aluno e os sujeitos que se responsabilizam pelo conteúdo do dizer, posto que assinam a matéria, passam a ser os professores e não quaisquer professores, são legítimos exemplares da "escola velha", que anulam (pelos riscos) o saber constitutivo da formação discursiva dos sujeitosalunos e colocam outros saberes no lugar, como se fossem os donos desse saber e, os legitimadores/constituidores de verdades, fechadas, saturadas, impermeáveis.

Diante do que se "viu/se leu/interpretou/compreendeu" podemos dizer que aqueles que escrevem para o professor e sobre os professores, na Revista Nova Escola, não são seus porta-vozes e, por isso, não há um "nós em construção", mesmo porque os educadores-sujeitos dessa matéria e os professores pertencem a dois grupos distintos: uns falam sobre os professores e sobre o ensino e os outros são professores e fazem educação, com teoria ou sem teoria eles 
estão lá, demandando por mudanças e talvez o discurso vazio, seja o início dos deslocamentos necessários. Ainda uma coisa: esse discurso em torno dos equívocos constitutivos dos discursos dos professores é ideológico e político e, muito provavelmente, ancore políticas educacionais em vigência. O certo é que por esse discurso retornam outros discursos, talvez aqueles discursos que representam os professores como detentores de discursos vazios, dos quais resultam efeitos de realidade instauradas por um discurso saturado, sem os furos próprios dele.

VENTURINI, M. C. Is the spokesagent always a "we" in construction? Alfa, v.56, n.1, p.293-308, 2012.

- ABSTRACT: Our object of study is the discourse about the teacher, as a discourse that supports itself in a discourse that we name "discourse by", and, in its workings, supports and legitimizes the knowledge and speech that surround the subjects. The corpus consists of issues of the Brazilian magazine Revista Nova Escola, widely known as "The-one-whoteaches magazine". We understand that this epithet levels both the teacher and the school, simulating the constitution of a "we", which leads us to ask the following question: Is the spokesagent always a "we" in construction? Our answer is "no", especially in the case that one of the elements of that "we" places itself in the position of the one that is in charge and is the spokesagent that has the power to say what is right and what is wrong. Our theoretical background is the Brazilian Discourse Analysis, and we thus consider the distinctions and reformulations undertaken by its proponents in relation to its French affiliation inaugurated by Pêcheux.

- KEYWORDS: Text. Discourse. Spokesagent. Image-Utterance. Discourse about. Discourse by.

\section{REFERÊNCIAS}

CONEIN, B. Décrire um evénement politique. In: COLLOQUE "MATERIALITES DISCURSIVES, 8., 1980, Nanterre. Anais... Paris: Université de Paris, 1980. p. 55-64.

COURTINE, J. J. O chapéu de Clémentis: observações sobre a memória e o esquecimento na enunciação do discurso político. In: INDURSKY, F.; FERREIRA, M. C. L. (Org.). Os múltiplos territórios da análise do discurso. Porto Alegre: Sagra Luzzatto, 1999. p.15-22.

Analyse du discours politique: le discours communiste adressé aux chrétiens. Langage, Paris, n.62, p.9-127, 1981.

DAVALLON, J. A imagem, uma arte de memória? In:ACHARD, P. et al. (Org.). Papel da memória. Tradução e introdução de José Horta Nunes. Campinas: Pontes, 1999. p.49-57.

DE CERTEAU, M. A invenção do cotidiano I: artes de fazer. Tradução de Ephraim Ferreira Alves. Petrópolis: Vozes, 1994. 
FOUCAULT, M. A ordem do discurso. Aula inaugural no Collége de France, pronunciada em 2 de dezembro de 1970. 10.ed. São Paulo: Edições Loyola, 2004.

INDURSKI, F. De ocupação a invasão: efeitos de sentido no discurso do/sobre o MST. In: INDURSKY, F.; FERREIRA, M. C. L. (Org.). Os múltiplos territórios da análise do discurso. Porto Alegre: Sagra Luzzato, 1999. p.173-186.

MALDIDIER, D. A inquietação do discurso: (re)ler Michel Pêcheux hoje. Tradução de Eni Orlandi. Campinas: Pontes, 2003.

MOÇO, A.; SANTOMAURO, B.; VICHESSI, B. O blábláblá da educação. Revista Nova Escola, São Paulo, ano 23, n.218, p.42-45, dez. 2008.

ORLANDI, E. P. Análise de discurso: princípios e procedimentos. Campinas: Pontes, 2002.

ORLANDI, E. P.; SOUZA, T. C. C. Efeitos do verbal sobre o não verbal. Revista Rua, Campinas, n.1, p.39-48, 1995.

PÊCHEUX, M. Semântica e discurso: uma crítica à afirmação do óbvio. Tradução de Eni Pulcineli Orlandi et al. 3.ed. Campinas: Ed. da UNICAMP, 1997.

. Delimitações, inversões e deslocamentos. Tradução de José Horta Nunes. Cadernos de Estudos Linguísticos, Campinas, v.19, p.7-24, 1990.

PROFESSORA do Instituto Estadual de Educação é agredida por aluno em Florianópolis. Diário Catarinense online, Florianópolis, 22 out. 1999. Disponível em: <http://diariocatarinense.clicrbs.com.br/sc/noticia/2009/10/professora-doinstituto-estadual-de-educacao-e-agredida-por-aluno-em-florianopolis-2692980. html>.

Acesso em: 28 out. 1999.

RANCIÈRE, J. Desentendimento: política e filosofia. Tradução de Ângela Leite Lopes. São Paulo: 34, 1996.

REVISTA NOVA ESCOLA. São Paulo, ano 23, n.218, dez. 2008.

ROSÁRIO, H. M. O sujeito do discurso e a noção de porta voz na mídia. In: MITTMANN, S.; CAZARIN, E. A.; GRIGOLETTO, E. Práticas discursivas e identitárias: sujeito e língua. Porto Alegre: Nova Prova, 2008. p.237-254.

SILVEIRA, V. F. P da. Imaginário sobre o gaúcho no discurso literário: da apresentação do mito em Contos gauchescos, de João Lopes Neto, à desmistificação em Porteira fechada, de Cyro Martins. 2004. 332p. Tese. (Doutorado em Letras) - Universidade Federal do Rio Grande do Sul, Porto Alegre, 2004.

SOUZA, T. C. C. de. A análise do não verbal e os usos da imagem nos meios de comunicação. Revista Rua, Campinas, n.7, p.65-94, 2001. 
VENTURINI, M. C. Imaginário urbano: espaço de rememoração/comemoração. Passo Fundo: Ed. da UPF, 2009a.

Leitura de um espaço urbano: subjetividade e poder das palavras. Desenredo: revista do Programa de Pós-graduação em Letras da Universidade de Passo Fundo, Passo Fundo, v.5, n.2, p.233-251, 2009b.

Recebido em junho de 2011.

Aprovado em outubro de 2011. 